\title{
Pembuatan, Karakterisasi dan Uji In Vitro Nanopartikel Emas Berbasis Konjugat Gom Arab-Vinkristin
}

\section{(Preparation of Gold Nanoparticles with Based on Conjugated Gum Arabic Vincristine and Evaluation of Their In Vitro Characteristics)}

\author{
RATIH DYAH PERTIWI ${ }^{1,4 *}$, JOSHITA DJAJADISASTRA ${ }^{1}$, ABDUL MUTALIB $^{2}$, \\ ANUNG PUJIYANTO ${ }^{3}$
}

\begin{abstract}
${ }^{1}$ Departemen Teknologi Farmasi Fakultas Farmasi Universitas Indonesia, Depok, Indonesia ${ }^{2}$ Departemen Kimia Fakultas Matematika dan Ilmu Pengetahuan Alam-Universitas Padjadjaran, Bandung, Indonesia

${ }^{3}$ Pusat Teknologi Radioisotop dan Radiofarmaka-Badan Tenaga Nuklir Nasional, Tangerang Selatan, Indonesia

${ }^{4}$ Program Studi Farmasi-Fakultas IImu Ilmu Kesehatan, Universitas Esa Unggul, Jakarta, Indonesia
\end{abstract}

Diterima 14 Desember 2017, Disetujui 22 Januari 2018

\begin{abstract}
Abstrak: Nanopartikel emas (AuNP) berpotensi dikembangkan sebagai nanomedik karena AuNP mudah disintesis, difungsikan, dan biokompatibel. Tujuan penelitian ini adalah mensintesis nanopartikel emas yang dikonjugasikan dengan vincristine, menggunakan gom arab sebagai penstabil. Sebagai agen pereduksi, digunakan larutan $0,02 \mathrm{M}$ Natrium Boro Hidrat $\left(\mathrm{NaBH}_{4}\right)$. Nanopartikel emas (AuNP) dilapisi dengan gom arab terkonjugasi (GA) dengan vincristine (VCR) berhasil disintesis dan dikarakterisasi. Konjugasi GA-VCR dan AuNP menunjukkan distribusi ukuran partikel hidrodinamik yang sempit dengan ukuran rata-rata $<100 \mathrm{~nm}$ oleh TEM dan PSA (particles size analyzer). Kami menyelidiki aktivitas sitotoksik dari nanopartikel emas tersebut menggunakan uji tetrazolium (MTT), dengan sel lestari leukemia CCR-CEM. Aktivitas sitotoksik konjugasi VCR-GA-AuNP sebelum dan sesudah pemurnian diuji dengan Size Exclusion Chromatography (SEC), terhadap CCRF-CEM, yang ditunjukkan oleh nilai $\mathrm{IC}_{50}$. Semua formulasi memiliki aktivitas sitotoksik dengan $\mathrm{IC}_{50}<20 \mu \mathrm{g} / \mathrm{mL}$. Nilai $\mathrm{IC}_{50}$ sampel terhadap sel CCRF adalah $1,026 \mu \mathrm{g} / \mathrm{mL}$ dan $2,607 \mathrm{ug} / \mathrm{mL}$. Dengan demikian, nanopartikel emas ini memberikan strategi yang menjanjikan untuk mengobati kanker.
\end{abstract}

Kata kunci: nanopartikel emas, vincristine, CCR-CEM.

\begin{abstract}
Gold nanoparticles (AuNP) are potentially developed as nanomedicine because AuNP is easily synthesized, functionalized, and biocompatible. The aim of this study was to synthesize gold nanoparticles conjugated with vincristine and gum arabic as a stabilizer. As a reducing agent, it used $0.02 \mathrm{M}$ Natrium Boro Hidrat $\left(\mathrm{NaBH}_{4}\right)$ solution. Gold nanoparticles (AuNP) coated with conjugated gum arabic (GA) and vincristine (VCR) were successfully synthesized and characterized. The conjugation of GA-VCR and AuNP displayed a narrow hydrodynamic particle size distribution with average size < $100 \mathrm{~nm}$ by TEM and PSA (particle size analyzer). We investigated the cytotoxic activity of conjugated vincristine-gum arabic-gold nanoparticle by tetrazolium salt assay (MTT) using cancer cell line CCRCEM. Cytotoxic activity of conjugated VCR-GA-AuNP before and after purification by Size Exclusion Chromatography (SEC), against leukemia cell line CCRF-CEM, was described by $\mathrm{IC}_{50}$ value. All formulation had a cytotoxic of activity with $\mathrm{IC}_{50}<20 \mu \mathrm{g} / \mathrm{mL}$. The $\mathrm{IC}_{50}$ of samples against CCRF cell line were $1.026 \mu \mathrm{g} / \mathrm{mL}$ and $2.607 \mathrm{ug} / \mathrm{mL}$, respectively. Accordingly, the gold nanoparticles render a promising strategy to treat cancer.
\end{abstract}

Keywords: gold nanoparticles, vincristine, CCR-CEM.

*Penulis korespondensi: $\mathrm{Hp}: 08159561966$

Email: ratdyp@gmail.com 


\section{PENDAHULUAN}

BARU-BARU ini nanopartikel emas menarik banyak perhatian karena bentuknya yang menarik dan ukurannya yang bergantung pada sifat fisik dan kimia, yang berbeda antara emas dan emas bulk. Selain itu, nanopartikel emas sangat menyerap cahaya di dalam wilayah spektrum yang tampak karena resonansi plasmon permukaan (Surface Plasma Resonance) dan mengubah cahaya yang diserap untuk keperluan pemanasan. Karakter partikel emas lainnya menjadi pertimbangan utamanya adalah kecenderungan untuk berkembang cukup tinggi untuk masuk ke pembuluh darah tumor. Saat ini, nanopartikel emas dianggap berguna untuk terapi fototermal dan juga untuk pencitraan dalam aplikasi biomedis. Partikel emas yang berada di dalam tumor bisa diiradiasi dengan sinar laser sehingga energi laser dapat dikonversi menjadi panas oleh partikel emas. Sel tumor dirusak oleh panas partikel emas sedangkan jaringan di sekitarnya hanya sedikit yang rusak. Jenis perawatan ini terbukti kurang invasif dengan efek samping yang lebih sedikit dan waktu pemulihan yang lebih singkat. Kelemahan nanopartikel emas umumnya mudah untuk memiliki agregasi dan hilangnya sifat foto unik mereka di bawah kondisi fisiologis. Untuk mengurangi agregasi fisiologis dalam larutan banyak digunakan zat penstabil, salah satunya adalah gom arab (GA). Konjugasi langsung molekul bioaktif menjadi nanopartikel emas selain meningkatkan stabilitas partikel juga meningkatkan kemampuan penargetan $^{(1)}$.

Gom Arab adalah polimer hidrokarbon glikoprotein yang tidak toksik dan banyak digunakan sebagai bahan penstabil atau agen pendispersi di industri makanan dan farmasi. GA telah digunakan untuk menstabilkan partikel. Muatan molekul GA (amina dan karboksilat) yang secara fisik dapat mengikat permukaan partikel. Melalui struktur polisakarida bercabang, GA dapat menyebabkan tolakan sterik di antara partikel sehingga meningkatkan stabilitas koloid. Penelitian juga menunjukkan bahwa nanopartikel emas dilapisi dengan larutan gom arab stabil pada serum albumin manusia dan lingkungan ionik yang kuat. Gom arab juga meningkatkan stabilitas partikel in-vivo dan juga mengandung kelompok karboksilat yang melimpah yang dapat dengan mudah diubah dan dihubungkan dengan biomolekul lainnya ${ }^{(2)}$.

Penelitian ini bertujuan untuk membuat persiapan konjugasi vinkristin dengan gom arab sebagai agen penstabil dan dilapisi dengan nanopartikel emas sebagai penghantar obat vinkristin agar dapat tertarget pada sel kanker yang dituju, mengkarakterisasi dan menguji efeknya dengan uji in vitro pada sel kanker yang spesifik (CCRF-CEM).

\section{BAHAN DAN METODE}

BAHAN. Bahan-bahan yang digunakan adalah vincristine powder (Sigma-Aldrich, Germany), $\mathrm{Au}$ foil, (Antam), gom Arab (Sigma-Aldrich), Natrium borohidrat (Merck, Germany), aqua bidestilata (IPHA, Indonesia), bovine serum albumin (Sigma-Aldrich), metanol (Sigma-Aldrich), phosphate buffer saline (IPHA), Lini Sel CCFRF-CEM (ATCC (American Type Culture Centre), MTT ([3-(4,5-dimethylthiazo2-yl-)-2,5-diphenyl tetrazolium bromide), human serum albumin (HSA) (Sigma Aldrich Jerman), Sephadex PD-10, PD-10 column (GE Health Care, Inggris), larutan $\mathrm{NaCl}$ fisiologis, Natrium dodecyl sulfat 10\%, RPMI, Aquades.

Alat. Alat yang digunakan adalah spektrofotometer UV-Vis V-550 (Jasco, Jepang), DTS Zetasizer Nano (Malvern Instrumen, Worcestershire, Inggris), Transmission Electron Microscope JEM- 1400 (JEOL Ltd., Jepang), Timbangan Analitik (Sartorius, Jerman), hotplate magnetic stirrer (Cimarec, Amerika), Inkubator, Neubauer Hemacytometer, Elisa Reader, pipet mikro adjustable (Eppendorf, Amerika), Syringe Milipore filter, thermostat (Polyscince, USA), refrigerated centrifuge (Beckman-Allegra, Amerika Serikat), Vortex, Effendorf 1,5 mL, mikroplate 96 well, Mikroskop Inverted, Tabung falcon, mikrotube, Whatman anopore (Sigma), kamera digital (Samsung), peralatan gelas seperti beaker glass (Pyrex, Amerika) dan erlenmeyer (Pyrex, Amerika).

METODE. Preparasi Larutan gom Arab. Gom Arab (0.61093 g) dilarutkan dalam $50 \mathrm{~mL}$ aqua bidestilata dan dipanaskan pada temperature 90-100 ${ }^{0} \mathrm{C}$ dengan pengadukan yang teratur ${ }^{(3)}$.

Konjugasi Gom Arab Vinkristine. Vinkristine $0.5 \mathrm{mg} / \mathrm{mL}$ sebanyak $2 \mathrm{~mL}$ dipipet dan dicampur dengan $10 \mathrm{~mL}$ larutan gom Arab dengan menggunakan probe homogenizer/sonikasi pada kecepatan 20.000 rpm selama 30 detik.

Konjugasi Vinkristin-Gum Arab-AuNP dengan Natrium Borohidrat. Pada Larutan $8.2 \mathrm{~mL}$ konjugasi vinkristin-gum Arab ditambahkan $1.5 \mathrm{~mL}$ $\mathrm{HAuCl}_{4} 0.002 \mathrm{M}$ dengan pengadukan terus menerus menggunakan stirer pada temperatur $55{ }^{\circ} \mathrm{C}$ dengan kecepatan $1.100 \mathrm{rpm}$ selama 3 jam. Larutan $0.2 \mathrm{M}$ $\mathrm{NaBH}_{4}$ sebanyak $25 \mathrm{~mL}$ ditambahkan dengan stirrer sampai terbentuk warna ungu kemerahan.

Pemurnian Konjugat dengan Size Exclusion Chromatography. Pemurnian dilakukan dengan Size Exclusion Chromatography dengan menggunakan Sephadex PD-10 sebagai penyaring. Fraksi hasil penyaringan ditampung dan dikarakterisasi dengan 
menggunakan spektrometer UV-VIS, distribusi ukuran partikel menggunakan Dynamic light scattering dan Transmission Electron Microscopy.

Karakterisasi dengan Spectrophotometer UVVisible. Karakterisasi konjugat menggunakan UV-VIS spectrophotometer UV-VIS pada panjang gelombang 400-800 nm.

Analisa Ukuran Partikel. Ukuran partikel dan zeta potential ditentukan menggunakan Zeta sizer Nano DTS and TEM.

Uji Sitotoksik. Sampel dengan konsentrasi yang dikehendaki (1,5625 ppm; 3,125 ppm; 6,25 ppm; 12,5 ppm; 25 ppm; 50 ppm) ditambahkan ke dalam sel dalam plat mikro, dikocok dengan mixer plate micro dan disimpan kembali dalam inkubator suhu $37{ }^{\circ} \mathrm{C}, \mathrm{CO}_{2} 5 \%$ selama 24 jam. Penambahan pereaksi MTT [3-(4,5-dimethylthiazo-2-yl-)-2,5-diphenyl tetrazolium bromide] $0,5 \mathrm{mg} / \mathrm{mL}$ sebanyak $100 \mu \mathrm{L}$ pada setiap sumuran dilakukan setelah 24 jam dari penambahan sampel, kemudian dikocok dengan mixer plate micro selama 2 menit, disimpan kembali dalam inkubator $\mathrm{CO}_{2}$. Empat jam kemudian, ditambahkan stop solution larutan SDS $100 \mu \mathrm{L}$ (Sodium Dodecyl Sulfat) $10 \%$, disimpan kembali dalam inkubator $\mathrm{CO}_{2}$ selama 24 jam. Pengukuran optical density (OD) dilakukan dengan menggunakan microplate reader selama 24 jam setelah penambahan stop solution. Uji aktifitas sitotoksik setiap bahan uji dievaluasi dengan menetapkan nilai $\mathrm{IC}_{50}$ (kadar yang diperlukan untuk menghambat pertumbuhan sel uji hingga 50\%) dianalisis dengan mendapatkan garis kurva setiap log konsentrasi bahan uji versus persentase jumlah kematian sel uji/probit ${ }^{(4)}$.

\section{HASIL DAN PEMBAHASAN}

Persiapan Pembuatan VCR-GA-AuNP. Persiapan pembuatan $\mathrm{HAuCl}_{4}$ dibuat dari $\mathrm{Au}$ foil dengan aqua regia sebagai pelarut yang mengandung $\mathrm{HCl}$ dan $\mathrm{HNO}_{3}$. Pilihan aqua regia sebagai pelarut karena $\mathrm{Au}$ adalah logam yang larut dalam aqua regia. Larutan $\mathrm{Au}^{3+}$ akan membentuk larutan kompleks yang stabil $\left[\mathrm{AuCl}_{4}\right]^{-}$, karena bereaksi dengan ligan $\mathrm{Cl}^{-}$dari $\mathrm{HCl}$.

Hasil konjugasi vinkristin dan gom arab menghasilkan larutan yang jernih. Pemilihan vinkristin sebagai obat yang dikonjugasi dengan gom arab adalah karena vinkristin memiliki sifat yang larut dalam air sehingga tidak memerlukan pelarut selain air suling. Selain itu, alkaloid vinca seperti vinkristin dengan kelompok $\mathrm{NH}_{2}$ (amina) mampu mengikat nanopartikel emas. Hal ini disebabkan terbentuknya interaksi yang kuat antara permukaan emas dengan molekul yang mengandung tiol/amina. Penambahan kelompok karboksilat bebas yang terkandung dalam gom arab dengan mudah akan digabungkan ke amina yang terkandung dalam vinkristin untuk menghasilkan konjugat kovalen dengan nanopartikel emas yang sangat stabil ${ }^{(5)}$.

Penyiapan nanopartikel emas dilakukan dengan metode bottom-up atau metode kimiawi dengan penambahan sodium borohidrat sebagai reduktor. Metode ini juga melibatkan agen stabilisasi bottomup untuk mencegah agregasi nanopartikel emas. Untuk itu, gom arab digunakan sebagai zat penstabil dalam larutan vinkristin dengan nanopartikel emas. Penambahan $25 \mathrm{~mL} \mathrm{0,2} \mathrm{M} \mathrm{NaBH}_{4}$ berfungsi sebagai reduktor dimana proses reduksi sempurna $\mathrm{Au}^{3+}$ ion menjadi $\mathrm{Au}^{0}$ ditandai dengan perubahan nanopartikel emas kuning menjadi ungu kemerahan. Perubahan warna disebabkan oleh nanopartikel emas yang memiliki resonansi plasma permukaan (Surface Plasmon Resonance) yang merupakan karakteristik partikel emas yang ditandai dengan perubahan penyerapan pada daerah $500-550 \mathrm{~nm}^{(6)}$.

Dari hasil spektrum absorbansi UV-Vis untuk larutan nanopartikel emas-vinkristin-gom arab, muncul absorbansi pada panjang gelombang 542 $\mathrm{nm}$ dibandingkan dengan spektrum gom arabvinkristin atau dengan larutan vinkristin yang muncul absorbansi pada panjang gelombang $295 \mathrm{~nm}$ (Gambar 1). Adanya absorbansi baru pada panjang gelombang $542 \mathrm{~nm}$ menunjukkan bahwa nanopartikel emas telah terbentuk sejak absorbansi nanopartikel emas memiliki puncak pada panjang gelombang 500-550 nm. Semakin tinggi nilai absorbansi, jumlah nanopartikel emas yang dihasilkan akan semakin banyak $^{(7)}$.

Adanya panjang gelombang puncak vinkristin pada $295 \mathrm{~nm}$ masih terlihat dalam larutan partikel emas emas-emas vinkristin-gom arab, hal ini menunjukkan bahwa vinkristin masih ada dalam larutan (Gambar 1). Untuk melihat apakah vincristin berkurang atau tidak karena proses penambahan zat pereduksi seperti $\mathrm{NaBH}_{4}$ maka harus dimurnikan dengan Size Exclusion Chromatography.

Pemurnian menggunakan Size Exclusion Chromatography. Tahap ini dilakukan dengan

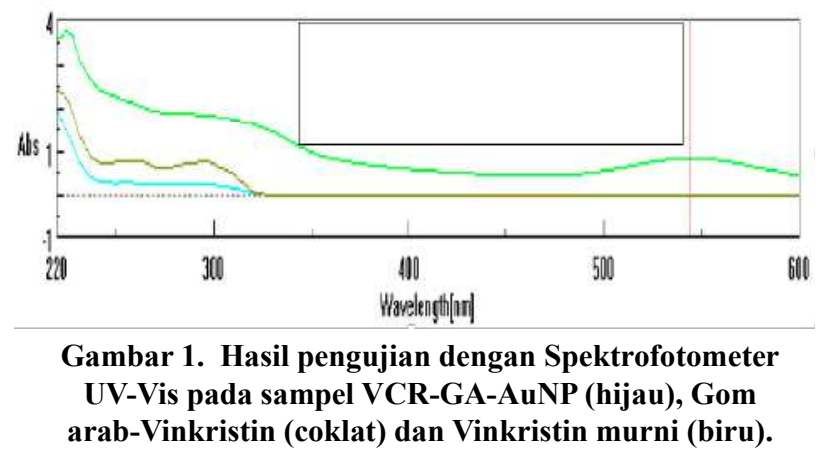


menggunakan kolom PD-10 yang mengandung medium sephadex G-25. Penggunaan kolom ini didasarkan pada perbedaan dalam kisaran ukuran molekul. Pemisahan optimum komponen sampel senyawa yang memiliki distribusi berat molekul yang luas dapat diperoleh jika kolom eksklusi memiliki rentang berat molekul yang berbeda. Bobot molekul $\mathrm{HAuCl}_{4}$, vinkristin, gom arab dan $\mathrm{NaBH}_{4}$ berturut turut adalah 1004,11; 339,7865; 250,000; dan 37,8325.

Dari berbagai bobot molekul di atas, maka pemurnian dengan menggunakan Size Exclusion Chromatography sangat efektif dilakukan untuk memisahkan kompleks nanopartikel emas-vinkristin -gom arab dengan vinkristin dan gold nanopartikel emas yang bebas. Penggunaan spektrofotometer UV-Vis yang dilakukan untuk mengidentifikasi luas permukaan respon plasma pada panjang gelombang 500-550 nm yang merupakan karakteristik absorbansi nano emas ${ }^{(7)}$.

Determinasi Ukuran Partikel dan Zeta Potensial. Nilai distribusi ukuran nanopartikel emas ditentukan dengan menggunakan Partikel Size Analyzer (PSA) dengan metode Dynamic Light Scattering (DLS). Dari hasil yang ditunjukkan pada Tabel 1, nilai diameter ukuran partikel untuk konjugat VCR-GA-AuNP sebelum dimurnikan menggunakan Size Exclusion Chromatography memiliki ukuran $48,39 \pm 15,85 \mathrm{~nm}$ dan konjugat VCR-GA-AuNP setelah pemurnian memiliki ukuran $8,435 \pm 1,646 \mathrm{~nm}$.

Kedua nilai pengukuran formula di atas menyatakan bahwa ukuran nanopartikel emas terbentuk di bawah $100 \mathrm{~nm}$, yang berarti bahwa formula dari dua larutan tersebut dalam ukuran nanomedicine. Nanopartikel berukuran antara 10-100 $\mathrm{nm}$ adalah ukuran kelas terapeutik untuk pengobatan $\operatorname{kanker}^{(8)}$.

Ukuran partikel setelah pemurnian menunjukkan hasil di bawah $100 \mathrm{~nm}$ dan lebih kecil dari ukuran partikel sebelum pemurnian. Hal ini menandakan bahwa dengan pemurnian dengan Size Exclusion Chromatography telah dihasilkan nanopartikel emas murni. Nilai indeks poli-dispersitas menunjukkan stabilitas sistem partikel nano, dimana nilai indeks poli-dispersitas yang meningkat mengindikasikan lebih banyak partikel teragregasi. Poli-dispersi mendekati 0 menunjukkan dispersi homogen. Sedangkan indeks poli-dispersi dengan nilai lebih dari 0,5 menunjukkan heterogenitas tinggi ${ }^{(8)}$.

Hasil untuk kedua formula tersebut menunjukkan indeks poli-dispersi pada kisaran 0,2-0,5 (Tabel 1). Ini menunjukkan bahwa kedua formula adalah larutan nanopartikel yang stabil karena partikel tidak banyak yang mengalami agregasi dan termasuk dispersi poli dalam rentang yang sempit.

Selain ukuran partikel, zeta potensial merupakan karakteristik penting pada nanopartikel, yaitu untuk memprediksi stabilitas larutan koloid. Interaksi antar partikel penting dalam stabilitas larutan koloid. Zeta potensial adalah nilai yang mengindikasikan kekuatan tolak menolak antar partikel. Zeta Potensial nanopartikel biasanya digunakan untuk mengkarakterisasi sifat muatan permukaan partikel nano Zeta potensial mencerminkan potensi listrik partikel dan dipengaruhi oleh komposisi partikel dan media di mana ia terdispersi. Nanopartikel dengan potensial di atas (+/-) $30 \mathrm{mV}$ telah terbukti stabil dalam suspensi, karena muatan permukaan mencegah agregasi partikel. Zeta potensial juga dapat digunakan untuk menentukan apakah bahan aktif yang terisi dienkapsulasi di dalam pusat nanocapsule atau teradsorpsi ke dalam permukaan ${ }^{(9)}$. Dari hasil zeta potensial untuk konjugat VCR-GA-AuNP sebelum pemurnian dan VCR-GA-AuNP setelah pemurnian,

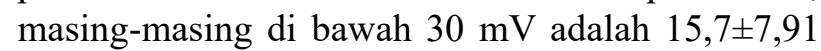
dan 15,7 $\pm 3,45$ (Tabel 1), yang berarti bahwa larutan nanopartikel di kedua formula tersebut merupakan larutan koloid yang belum cukup stabil dengan muatan negatif.

Uji Morfologi dengan Transmission Electron Microscope (TEM). Transmission Electron Microscope digunakan untuk meneliti morfologi nanopartikel emas dan konfirmasi ukuran partikel yang

Tabel 1. Distribusi diameter ukuran partikel, indeks polidispersitas dan zeta potensial.

\begin{tabular}{lclc}
\hline Formula & $\begin{array}{c}\text { diameter partikel } \\
(\text { d.nm })\end{array}$ & $\begin{array}{l}\text { Indeks } \\
\text { Poiddspersitas }\end{array}$ & $\begin{array}{c}\text { Zeta } \\
\text { Potential }\end{array}$ \\
\hline $\begin{array}{l}\text { VCR-GA-AuNP } \\
\text { Sebelumpenurnian }\end{array}$ & $48,39=15,85$ & 0,251 & $15,7 \pm 7,91$ \\
$\begin{array}{l}\text { VCR-GA-AuNP } \\
\text { Setelah pemumian }\end{array}$ & $8,435 \pm 1,646$ & 0,462 & $15,7 \pm 3,45$ \\
\hline
\end{tabular}

dihasilkan dari pengukuran distribusi ukuran partikel. Pada hasil TEM, formula ukuran partikel VCR-GAAuNP sebelum dan sesudah pemurnian menggunakan Size Exclusion Chromatography menunjukkan bahwa perbedaan ukuran nyata dimana VCR-GA-AuNP setelah pemurnian lebih kecil dari pada VCR-GAAuNP sebelum pemurnian pada skala $20 \mathrm{~nm}$ dan $50 \mathrm{~nm}$ (Gambar 3). Hal ini menunjukkan bahwa pemurnian dengan Size Exclusion Chromatography merupakan metode yang efektif sebagai metode pemurnian untuk memisahkan nanopartikel emas dengan ukuran besar.

Uji Sitotoksisitas dengan Lini Sel CCRF-CEM. Uji sitotoksisitas pada penelitian ini dilakukan untuk menggambarkan kemampuan konjugat-VCR-GAAuNP dalam memberikan efek toksik pada sel CCRF 


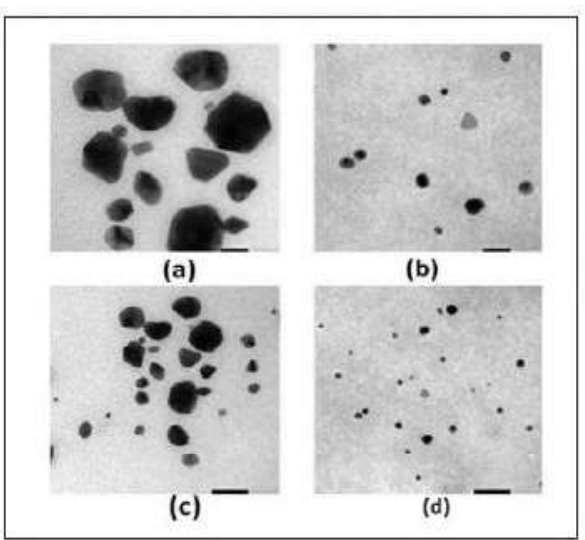

Gambar 3. Morfologi VCR-GA-AuNP

(a) sebelum pemurnian pada skala $20 \mathrm{~nm}$

(b) sesudah pemurnian pada skala $20 \mathrm{~nm}$

(c) sesudah pemurnian pada skala $50 \mathrm{~nm}$

(d) sesudah pemurnian pada skala $50 \mathrm{~nm}$

yang dinyatakan pada nilai $\mathrm{IC}_{50}$ (konsentrasi senyawa uji yang mampu menghambat $50 \%$ pertumbuhan sel). Dalam uji lini sel ini, pengamatan dilakukan dengan uji viabilitas sel MTT [3- (4,5-dimetiltiazol-2-yl) -2,5 difenil tetrazolium bromida] dan penggunaan CCRF.

Metode perubahan warna digunakan untuk mendeteksi proliferasi sel. Sel yang mengalami proliferasi, MTT akan menyerap sel ini sehingga sel akan berwarna ungu karena terbentuk kristal tetrazolium (formazan). Formazan dapat dilarutkan dan menghasilkan sinyal kolorimetri yang bergantung pada konsentrasi pada $570 \mathrm{~nm}$ yang sebanding dengan jumlah sel dan aktivitas sel (Gambar 2).

Uji sitotoksik menggunakan 3 sampel, yaitu konjugat VCR-GA-AuNP sebelum pemurnian, VCRGA-AuNP setelah pemurnian dan kontrol positif menggunakan vinkristin murni. Sampel disiapkan dalam 4 pengenceran (25 ppm; 12,5 ppm; 6,25 ppm; $3,125 \mathrm{ppm}$ ) dan masing-masing bahan dievaluasi dengan menetapkan nilai $\mathrm{IC}_{50}$. Penentuan apakah suatu zat dikembangkan sebagai obat anti kanker atau tidak didasarkan pada sifat toksisitasnya. National Cancer Institute (NCI) telah menetapkan kriteria aktivitas berdasarkan nilai konsentrasi penghambatan 50 $\left(\mathrm{IC}_{50}\right)$ yang merupakan konsentrasi yang dibutuhkan
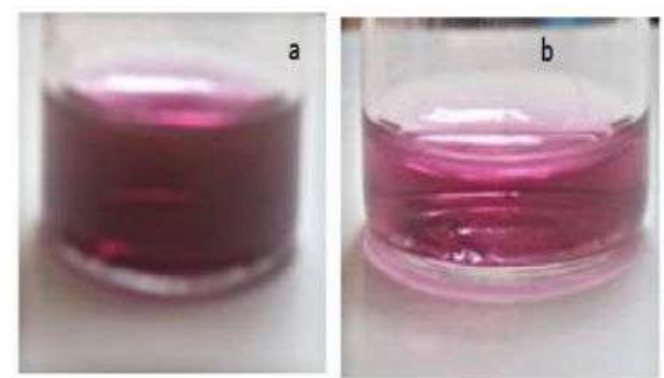

Gambar (2a). Formula VCR-GA-AuNP sebelum pemurnian (2b) Formula VCR-GA-AuNP sesudah pemurnian. untuk menghambat pertumbuhan sel hingga 50\%. Substansi yang ditunjukkan memiliki efek sitotoksik bila aktivitas sel yang diuji memiliki nilai IC50 $<20$ $\mathrm{mg} / \mathrm{mL}$ untuk ekstrak, dan nilai IC $50<4 \mathrm{mg} / \mathrm{mL}$ untuk senyawa murni ${ }^{(10)}$.

Hasil $\mathrm{IC}_{50}$, baik dalam bentuk VCR-GA-AuNP sebelum dan sesudah pemurnian berturut-turut adalah 1,02 g/mL dan 2,60 g/mL (Tabel 2). Hal ini menunjukkan bahwa hasil konjugasi nanopartikel emas dengan senyawa vinkristin adalah senyawa aktif dan terkonjugasi dengan baik. Sedangkan sampel setelah dimurnikan mengalami penurunan aktivitas

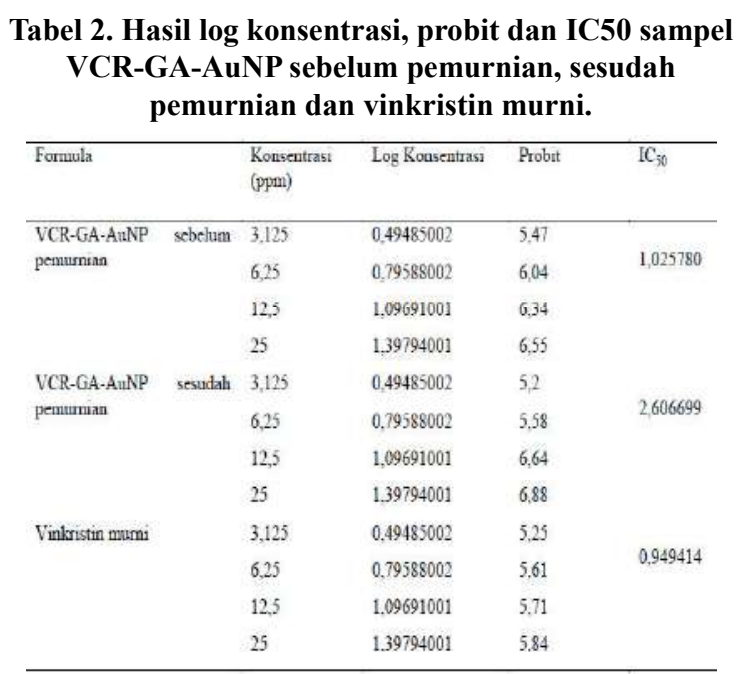

dibandingkan dengan pemurnian sebelumnya, walaupun masih di bawah 10 ppm dan termasuk kategori aktif. Kemungkinan hal ini disebabkan karena ada beberapa kelompok yang menjadi tidak aktif karena adanya konjugasi.

\section{SIMPULAN}

Persiapan nanopartikel emas yang terkonjugasi dengan gom arab dan vinkristin menunjukkan distribusi ukuran partikel hidrodinamik yang sempit dan hasil pengujian in vitro sebelum dan setelah pemurnian dengan menngunakan lini sel CCRF-CEM menghasilkan $\mathrm{IC}_{50}$ berturut turut adalah $1,025780 \mathrm{mg} / \mathrm{mL}$ dan $2,606699 \mathrm{mg} / \mathrm{mL}$.

\section{UCAPAN TERIMA KASIH}

Penelitian ini disponsori oleh hibah dari Direktorat Riset dan Pengabdian Masyarakat, Universitas Indonesia dan penulis menerima dukungan dari Pusat Teknologi Radioisotop dan Radiofarmaka-Badan Tenaga Nuklir Nasional, Indonesia karena menyediakan fasilitas yang diperlukan untuk melaksanakan pekerjaan ini. 


\section{DAFTAR PUSTAKA}

1. Kojima C, Hirano Y, Yuba E, Harada A, Kono K. Preparation and characterization of complexes of liposomes with gold nanoparticles. Colloids Surf B Biointerfaces. 2008. 66(2):246-52.

2. Zhang L, Yu F, Cole AJ, Chertok B, David AE, Wang $\mathrm{J}$, et al. Gum arabic-coated magnetic nanoparticles for potential application in simultaneous magnetic targeting and tumor imaging. AAPS J. 2009. 11(4):693-9.

3. Pujiyanto A, Mujinah, Lubis H, Witarti, Setiawan $\mathrm{H}$, Dede K, et al. Penggunaan gum arab sebagai stabilisator nanopartikel emas untuk diagnosis dan terapi kanker. Pros Semin Nas Sains Dan Pendidik IX Fak Sains Dan Mat UKSW Salatiga. 2014. V(1):486-90.

4. Doyle A, Griffiths J. Cell and tissue culture for medical research. British, Wiley. 2000. 409-10.

5. Vigderman L, Zubarev ER. Therapeutic platforms based on gold nanoparticles and their covalent conjugates with drug molecules. Adv Drug Deliv Rev. 2013. 65(5):663-76

6. Esumi K, Suzuki A, Yamahira A, dan Torigoe K. Role of poly (amidoamine) dendrimers for preparing nanoparticles of gold, platinum, and silver. 'langmuir 16. 2000. 2604-2608.

7. Wu C-C, Chen D-H. Facile green synthesis of gold nanoparticles with gum arabic as a stabilizing agent and reducing agent. Gold Bull. 2010. 43(4):234-40.

8. Wang X, Wang Y, Chen ZG, Shin DM. Advances of cancer therapy by nanotechnology. Cancer Res Treat. 2009.41(1):1.

9. Mohanraj VJ, Chen Y. Nanoparticles-a review. Trop J Pharm Res. 2006. 5(1):561-73.

10. Suffness M, JM Pezzuto. Assays related to cancer drug discovery. In: Methods in Plant Biochemistry: Assays for Bioactivity. London: Academic Press; 1990. 71-133. 